\title{
DOES A SPONTANEOUS CURE FOR CHAGAS' DISEASE EXIST?
}

\author{
Rodrigo Zeledón 1 , João Carlos P. Dias², A. Brilla-Salazar ${ }^{3}$, \\ J. Marcondes de Rezende ${ }^{4}$, Luis G. Vargas ${ }^{1}$ and Andrea Urbina1.
}

\begin{abstract}
Six Costa Rican Chagas' disease patients, with wellknown acute phase history and no specific treatment were examined in several occasions during 39,24,32, 16 and 14 years, respectively, from the onset. Nome of the patients presented heart abnormalities as revealed by the conventional EKG and ergometry, except for one of them with an incomplete block of the right bundle branch. Also, no alterations of the oesophagus motility was detected manometrically except for another patient who presented a slight hypersensivity reaction to a pharmacological test (Mecholyl). Three out of six patients became serologically negative in 1981, remaining as such until 1986. Besides the conventional serology, the search of protective ("lytic") antibodies was also performed in 1985 and 1986, being completely negative in one of the "cured" patients and dubious in the other two. The hypothesis that these three patients had as spontaneous cure, based on the clinical, serological and parasitological findings is discussed.
\end{abstract}

Key words: American trypanosomiasis. Chagas' disease. Spontaneous cure. Longitudinal studies.

Chagas' disease, or American trypanosomiasis, is endemic in most Latin American countries where it is transmitted by several species of triatomine bugs. Its incidence and prevalence varies within different geographical areas and this seems to be related, as least in part, to the relative abundance, within a house, of the particular species of vector involved $^{2} 20293133$.

After an acute phase, which is not always detected, a chronic phase is stablished. In some cases it may take as long as 20 years after the acute onset for the pathological manifestations to appear (e.g. alterations of the heart or the digestive tract) $)^{2} 81018192223$.

Since all patients in the asymptomatic or indeterminate phase remain serologically positive for the specific antigen, they have been considered potential victims for the tissue damage that leads to the different manifestations of the disease $e^{1811} 1518202425$.

In the following paragraphs we present evidence supporting current observations that several patients

1. Proyecto de Zoonosis, Escuela de Medicina Veterinária, Universidad Nacional, Heredia, Costa Rica.

2. Fundação Oswaldo Cruz \& Universidade Federal de Minas Gerais. Divisão de Doença de Chagas, SUCAM, Ministério da Saúde, Brasília, DF, Brasil.

3. Servicio de Cardiologia, Hospital México, San José, Costa Rica.

4. Faculdade de Medicina, U.F. Goiás, Goiânia, GO, Brasil.

Endereço: João Carlos Pinto Dias. SUCAM, Ministério da Saúde, Esplanada dos Ministérios, Bloco G, anexo A, 70058 Brasilia.

Recebido para publicação em $8 / 6 / 87$. who had an evident acute phase and no specific chemotherapy remain asymptomatic for long periods of time. Also, as a new hypothesis, that some of them may suddenly become serologically negative suggesting that they evolve towards spontaneous cure of the infection 3471722 .

\section{METHODOLOGY AND HISTORY OF THE CASES}

In a general way this work is a part of epidemiological studies about Chagas' disease that have been carried out in Costa Rica since several years by one of us $(Z$.). The clinic and laboratorial follow-up of some cases that have presented a typical acute phase constitute a routine that includes physical examination, electro-cardiogram (EKG), X-ray of the chest, xenodiagnoses and conventional serology 182328 . The xenodiagnoses were initially performed with about 10 third instar nymphs of Triatoma dimidiata, but after 1981 Dipetalogaster maxima was introduced ( 10 or 20 first instar nymphs per patient). Conventional serologic tests to detect IgG antibodies anti $T$. cruzi were performed in Costa Rica and foreign laboratories, utilizing four common tests: complement fixation tests (CFT), indirect hemagglutination (IHT), indirect immunofluorescence (IIFT) and direct agglutination (DAT). All the sera were collected by venous punction and preserved in deep freezers $\left(-20^{\circ} \mathrm{C}\right)$. Transportation for other countries was made in ice, by airplane. The used serologic techniques are described by Guimarães ${ }^{14}$. Non-conventional serology was also applied in order to look for "protective" or "lytic" antibodies, in René Rachou Centre, Belo Horizonte, Brazil, by 
Drs. A. Krettli and Z. Brener. The technique utilized was immunofluorescence with living trypomastigotes test (ITLT), consisting of treating living $T$. cruzi trypomastigotes pre-incubated with diluted sera in the presence of sodium azide at $4 . \mathrm{O} \mathrm{C}$ then washed and fixed, plus a fluorescein-conjugated $\operatorname{IgG} 17$.

In order to detect incipient chagasic lesions of the heart and oesophagus, in 1983 and 1984 these patients were respectively submitted to ergometric tests, oesophagus manometry and mecholyl tests ${ }^{11} 12$ 1324 . Ergometry was performed in a conventional track apparatus, through progressive tests monitorized by EKG and blood pressure ${ }^{11}$. Mecholyl test is a pharmacological technique that employs a cholinergic stimulus (metacholine chloride N.F.) which is able to put in evidence some alterations of the oesophagus intrinsic innervation 121324 .

In the following summarized description the main objective is to characterize the acute phase and the clinical and laboratorial evolution of each case.
All the six cases presented a typical picture of acute Chagas' disease and four of them had the Romaña sign. The direct blood examination was positive for $T$. cruz $i$ in five patients, while xenodiagnoses were positive in all of them during the acute onset. The patient whose direct examination was negative was M.C.Ch. (case no 2). She entered the hospital with fever, splenomegaly, tachicardia and generalized oedema. Acute Chagas' disease was suspected by Dr. Arturo Romero, being confirmed by xenodiagnosis 28 . Triatoma dimidiata was found in the houses of all the patients. None of these patients had never received specific treatment against $T$. cruzi. More detailed information on clinical and laboratorial findings of these cases as well as epidemiological data related to them were presented in different publications 28293234 .

Table 1 summarizes the main clinical, epidemiological and laboratorial data concerning this group of patients. Table 2 presents the traditional serology performed in 1985 and 1986 and table 3 shows the results of non-conventional serology (ITLT).

Table 1 - Characteristics of the evolution of 6 chronic cases of Chagas' disease parasitologically positive at the acute onset

\begin{tabular}{|c|c|c|c|c|c|}
\hline Patients & Year of infection & Time (years) & Serology & & Manometric \\
\hline $\begin{array}{l}\text { No Name } \\
\text { (initials) }\end{array}$ & clinical findings & infection (1985) & a) Conventional (1) b) I. T. L.T. (2) & $\begin{array}{c}\& \\
\text { Ergometry } \\
(1983)\end{array}$ & $\begin{array}{c}\text { oesophagus } \\
\text { (1984) }\end{array}$ \\
\hline
\end{tabular}

1.M.C.R.M. F $44 \quad 1946$ Romaña's sign

2. M.C.Ch. F $49 \quad 1951$ Generalized edema, fever splenomegaly

3. F.B. M Romaña’s sign

4. J.R.M.A. M 571953 Romaña's sign

$\begin{array}{lrrl}\text { 5. M.A. } & \text { F } & 23 & \begin{array}{l}1969 \\ \text { Acute myocarditis, } \\ \text { fever, adenopathies } \\ \text { 6. F.Ch.V. }\end{array} \text { F } \\ \text { Romaña's sign }\end{array}$

Positive (1973) ? (3)
Negative (1981,
$83,84,85$ \& 86)

Positive (1981, $83,84,85$ \& 86 )

\section{Positive (1973)}

Negative (1981, $83,84,85$ \& 86)

Positive (1973)

Negative (1981, $83,84,85 \& 86$ )

Positive (1973, Positive $81,83,84,85$ \& 86)

Positive (1973, Positive $81,83,85 \& 86)$
Incomplete Normal block of right bundle branch

Normal (4) Normal

Normal (4) Normal

Normal Normal (5)

Normal (4) Normal

Normal (4) Normal

\footnotetext{
Conventions: (1) Complement fixation or immunofluorescence or haemagglutination or direct agglutination tests. (2): Immunofluorescence test performed with living trypomastigotes. (3): dubious result. See the text and Table 3. (4): A new EKG performed in 1985 shwed the same result. (5): Slight hypersensitivy of distal part to Mecholyl (13).
} 
Table 2-Recent results of Costa Rican patients with two conventional serologic techniques do detect specific anti-T. cruzi antibodies*

\begin{tabular}{llllll}
\hline $\begin{array}{l}\text { Patients } \\
\text { No (initials) }\end{array}$ & IIFT & IHT & IIFT 25/06/1986 Final & Final \\
\hline I M.C.R.M. & Neg. $(1: 20)$ & Neg. & $1: 8$ & IHT & Interpretation \\
2 M.C.Ch. & $1: 1,024$ & Pos. & $1: 128$ & $1: 8$ & Negative \\
3 F.B. & Neg. & Neg. & Neg. & $1: 512$ & Positive \\
4 J.R.M.A. & Neg. & Neg. & $1: 8$ & Negative \\
5 M.A. & $1: 256$ & Pos. & $1: 128$ & $1: 8$ & Negative \\
6 F.Ch.V. & $1: 512$ & $1: 16$ & $1: 32$ & $1: 128$ & Positive \\
\end{tabular}

IIFT: Indirect immunofluorescence test.

IHT: Indirect haemagglutination test.

* Serology performed by the Seroepidemiology Laboratory.

Ezequiel Dias Foundation, Belo Horizonte, Brazil

(Dr. Hélène D’Hooge).

Table 3 - Chagas' disease. Results of three tests perfomed in Costa Rican sera with the non-conventional immunofluorescence technique made with living trypomastigotes, $1986 .{ }^{\circ}$

\begin{tabular}{lllccc}
\hline N.o & $\begin{array}{l}\text { Patients: } \\
\text { (initials) }\end{array}$ & Test 1 & $\begin{array}{c}\text { Results } \\
\text { Test } 2\end{array}$ & Test 3 & $\begin{array}{c}\text { Final } \\
\text { Interpretation }\end{array}$ \\
\hline 1 & M.C.R.M. & Posit. & Negat. & Dubious & Dubious \\
2 & M.C.Ch. & Negat. & Posit. & Posit. & Positive \\
3 & F.B. & Negat. & Negat. & Negat. & Negative \\
4 & J.R.M.A. & Posit. & Dubious & Negat. & Dubious \\
5 & M.A. & Posit. & Posit. & Posit. & Positive \\
6 & F.Ch.V. & Posit. & Posit. & Posit. & Positive \\
\hline
\end{tabular}

* Sera performed in the laboratories of René Rachou Research Centre, Belo Horizonte, MG, Brazil (Drs. Zigman Brener \& Antoniana U. Krettli).

\section{DISCUSSION}

The fact that three of this special group of six Costa Rican patients became serologically negative after a certain period of time is a strong evidence, in our opinion, that they evolved towards a spontaneous cure. It is important to note that all these patients have a well documented acute phase and never received specific treatment for Chagas' disease. More over all of them have been clinically well during all the period after the acute disease, none of them presenting any evidence of immunodepression 6 .

The persistent and definitive reversion of the serology from positive to negative results is considered nowadays as the most important cure criterion of human Chagas' disease 791617 19. Sporadic negative tests can be observed in a few chronic non-treated patients, sometimes in the very same day in wich xenodiagnoses was found to be positive ${ }^{1926}$. Nevertheless, this fact is exceptional in longitudinal studies in endemic areas where normally the serological tests become positive again in further observations 34102223 . In experimental laboratory models spontaneous cure of $T$. cruzi infections was recently observed in opossuns, with persistent negative parasitological and serological tests (including the research of lytic antibodies ${ }^{1727}$. By another way the revertion of the serological tests to negative results has been observed in human chagasic patients treated with specific chemoterapy in the acute phase $^{79} 17$.

There is evidence that cured and/or non infected individuals do not present immunoglobulins directed to epitopes expressed on the membrane of living trypomastigotes. Such immunoglobulins are the same protective antibodies responsible for the acquired resistance displayed by the infected host 1617 . These "functional" antibodies may disappear 5-7 months after a succesfull treatment, while conventional serolo- 
gy can persist positive for up to 4 years in such cases 7 17. It is important to observe that our cases no $1,3 \& 4$ have shown negative results for conventional serology since 1981, after many examinations and using different techniques. The titres about 8 in some recent tests of the patients n. 1 \& 4 are very inespecific and must be considered negatives according to current experience 1317.

The diagnostic value of non-conventional serology is very high, chiefly considering the negative results (sensibility) 617 . Some operational problems with false positive sera may exist and may have occurred in our patients Nos 1 and 4 (Table 3). It has been frequently found some dubious results, mainly in periods immediatly before the definitive convertion of the test to negative outcomes ${ }^{7}$ 17. For the patient no 3 both conventional and non-conventional methods showed consistent negative results, what strongly suggest the possibility of spontaneours cure 5791719 . As recently pointed out by Luquetti ${ }^{19}$ the same possibility exists for the patients $N$.os $1 \& 4$, whose conventional serology have persisted negative for 6 years or more. It is convenient to follow these patients for at least further two or three years in order to analyse the real behaviour of their clinical and immunological pictures ${ }^{7}$ 17. Nevertheless the case No 3 at once can be. considered cured, fact that certainly represents and exception in the natural history of human Chagas' disea-

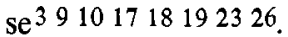

The patients n: $2,5 \& 6$ still present positive serology and correspond to the absolute majority of the cases that are being studied in endemic areas and longitudinal studies 37101923 . None of those cases have shown any important pathological alteration attributable to the disease respectively after 39,34 and 32 years. They remain in the so called "indeterminate" form of chronic Chagas' disease and present a very good prognosis 21011182225 .

The border-line alterations observed in the EKG of patient No 1 and the mecholyl test of patient No 4 are not to be considered as signs of active Chagas' disease $^{2} 10$, since both alterations can be seen in noninfected people as well as in chagasic people due to residual lesions occurred in the past ${ }^{2} 1518$. In the specific case of hypersensitivity to the mecholyl test it only represents a moderate denervation of the intrinsic para-sympathetic plexus of the oesophagus, independently of the aetiological factor 121324 .

Chagas' disease in Costa Rica has been well demonstrated in several publications, with a serological prevalence of $11.7 \%$ in a group of 1,420 people from an area infested with Triatoma dimidiata ${ }^{34}$. Some local peculiarities such as the absent (or extremely low) prevalence of digestive "mega" syndromes are being now studied in the same regional difference context of Chagas' disease 20212830 .
This paper suggest that some patients could evolve to spontaneous cure of Chagas' disease after many years of active infection. It remains to be demonstrated whether this phenomenon, here reported for Costa Rican patients also occurs in other Latinamerican areas where this trypanosomiasis is endemic. This possibility has recently been considered by Arribada $e t$ $a l$ in Chile ${ }^{4}$ and Luquetti, in Brazil ${ }^{19}$, but how frequen the fact occurs and the reason of that occurrence remain to be investigated.

\section{RESUMO}

Um grupo de pacientes com doença de Chagas vem sendo acompanhado desde a fase aguda, na Costa Rica, com tempos de evolução entre 14 e 44 anos (mediana de 32 anos). Em todos a doenca aguda foi bem comprovada, não sendo realizado tratamento especifico em nenhum deles, contra o Trypanosoma cruzi. Todos apresentaram pelo menos uma sorologia positiva ao longo da fase crônica, mas em três deles as técnicas sorológicas convencionais se tornaram parmanentemente negativas em diversos exames ealizados em diferentes laboratórios, entre 1981 e 1986. Nestes três pacientes também a pesquisa de anticorpos líticos foi negativa (um caso) ou negativo-duvidosa (dois casos), permanecendo consistentemente positiva nos três outros pacientes com sorologia convencional reagente. Atualmente todos os seis pacientes se apresentam assintomáticos e com xenodiagnóstico negativo. Apenas um deles apresenta distúrbio eletrocardiográfico mínimo e inespecífico (bloqueio incompleto do ramo direito) e, um outro, pequeno retardo do trânsito esofagiano à prova de metacolina. Levanta-se a hipótese de cura espontânea da doença de Chagas, fato que deve ser raro $e$ que merece maior investigação.

Palavras Chaves: Tripanosomiase americana. Doença de Chagas. Cura espontânea. Estudo longitudinal.

\section{ACKNOWLEDGEMENTS}

This work was in part sponsored by a TDR (UNDP/WB/WHO) grant. We are grateful to Drs. Mário E. Camargo (Instituto de Medicina Tropical de S. Paulo, Brasil), Jorge E. Yanowsky (Fundación Polychaco, Buenos Aires, Argentina), Zigman Brener and Antoniana U. Krettli (Centro de Pesquisas René Rachou, Belo Horizonte, Brasil) and Hélène D'Hooge (Fundação Ezequiel Dias, Belo Horizonte, Brasil) for their precious help with the serology, and to Dr. Phillip D. Marsden (Universidade de Brasillia), for the revision of the manuscript. 


\section{REFERENCES}

1. Andrade ZA. Aspectos patológicos da doença de Chagas. Interciência 8: 367-373, 1983.

Andrade ZA, Andrade SG. Patologia. In: Brener Z, Andrade $\mathrm{Z}$ (ed.) Trypanosoma cruzi e doençade Chagas. Guanabara Koogan Ed. Rio de Janeiro. 1979.

3. Apt W, Arribada A, Cabrera L. Sandoval I. Natural history of chagasic cardiopathy in Chile. Follow-up of 71 cases after 4 years. Journal of Tropical Medicine. 86: 217-222, 1986.

4. Arribada A, Apt W Ugarte IM. A four year follow-up survey of chagasic cardiopathy in Chile. Pan American Health Organization Bulletin 20: 245-266, 1986.

5. Brener Z, Andrade Z (ed.) Trypanosoma cruzi e doença de Chagas, Guanabara Koogan, Ed. Rio de Janeiro, 1979.

6. Breniere F, Poch G, Selaes H, Tibayrene M, Lemestre FL, Antezana G, Desjeux P. Specific humoral depression in chronic patients infected by Trypanosoma cruzi. Revista do Instituto de Medicina Tropical de São Paulo, 26: 254-258, 1984.

7. Cançado JR. Tratamento específico. In: Cançado JR., Chuster M. (ed.) Cardiopatia Chagásica. Fundação Carlos Chagas Ed. Belo Horizonte, 1985.

8. Carrasco HA, Palacios-Pru E, Mendonza RV, Dagert de Scorza C. Aspectos clínicos de la enfermedad de Chagas. Diagnóstico de daño miocárdico. Interciencia, 8:342-352, 1983.

9. Cerisola JA. Valor del immunodiagnóstico en la infección chagásica. In: Simpósio Internacional de Enfermedad de Chagas. SociedadeiArgentina de Parasitologia: Ed. Buenos Aires, 1972.

10. Dias JCP. Doença de Chagas em Bambui, Minas Gerais, Brasil. Estudo clínico-epidemiológico a partir da fase aguda, entre 1940 e 1982. Tese, Faculdade de Medicina da Universidade Federal de Minas Gerais, 1982. Minas Gerais, 376 p., 1982.

11. Faria CAF. Ergometria na avaliação clínica da doença de Chagas crônica. In: Cançado JR, Chuster M. (ed.) Cardiopatia Chagásica. Fundação Carlos Chagas Ed., Belo Horizonte, 1985.

12. Godoy RA. Estudo da esofagopatia chagásica crônica por meio do método eletromanométrico e da prova da metacolina em pacientes com e sem dilatação do esôfago. Revista Goiana de Medicina 18: 1-73, 1972.

13. Godoy RA., Vieira CB. Effects of cholinergic drugs on the oesophagus of patients with Chagas disease.Acta Physiologia Latinoamericana 11: 107, 1961.

14. Guimarāes MCS. Chagas' disease serology: specifications and evaluations methods for immunological reagents. PAHO/WHO Washington, 1984.

Brazilian forms of Chagas'disease? Lancet, 1:1338-1340,

15. Koberle F. Pathogenesis of Chagas' disease. Ciba Foundation Simposium 20: 137-158, 1974.

16. Krettli AU. Resposta imune humoral na doença de Chagas. Interciencia 8: 374-383, 1983.

17. Krettli AU, Cançado JR., Z.Brener. Criterion of cure of human Chagas' disease after specific treatment: re- cent advances. Memorias do Instituto Oswaldo Cruz, 79 (supl.): 157-164, 1984.

18. Laranja FS, Dias E, Nóbrega G, Miranda A. Chagas' disease. A clinical, epidemiologic and pathologic study. Circulation 14: 1035-1060, 1956.

19. Luquetti AO. Contribuição ao estudo epidemiológico, sorológico e parasitológico do megaesôfago chagásico. Dissertação de mestrado. Instituto de Patologia Tropical e Saúde Pública, Universidade Federal de Goiás, Goiânia, 1987.

20. Maekelt GA. La epidemiologia de la enfermedad de Chagas en relación con el ecosistema domiciliario. Interciencia 8: 353-366, 1983.

21. Miles MA, Cedilhos RA, Povoa MM, Souza AA., Prata A, Macedo V. Do radically dissimilar Trypanosoma cruzi strains (Zymodemes) cause Venezuelan and Brazilian forms of Chagas' disease?. Lancet, 1:1338-1340, 1981.

22. Prata A, Macedo VO. Morbidity of Chagas' heart disease. Memórias do Instituto Oswaldo Cruz 79 (Supl.): 93-96, 1984.

23. Puigbo JJ, Nava Rhode JR, Barrios HG, Yepez CG. Cuatro af́os de estudio longitudinal de una comunidad rural con endemicidad chagásica. Boletin de la Oficina Sanitaria Panamericana 48:112-120, 1969.

24. Rezende JM. Clínica: Manifestações digestivas. In: Brener Z. \& Andrade Z.(ed.) Trypanosoma cruzi e Doença de Chagas. Guanabara Koogan Ed. Rio de Janeiro, 1979.

25. Rosenbaum MB., Cerisola JA. Epidemiologia de la enfermedad de Chagas en la República Argentina. $O$ Hospital 60:55-100, 1961.

26. Salgado AA, Mayrink W., Dias JCP. Estudo comparativo entre reação de fixação de complemento com os antígenos benzeno cloroformado e metílico e o xenodiagnóstico. Revista do Instituto de Medicina Tropical de São Paulo 12: 36-40, 1970.

27. Thomaz N., Jansen AM, Deane MP. Trypanosoma cruz $i$ : the complemente-mediated lysis (CoML) in experimentally infected opossums Didelphis marsupialis. XI Reuniāo Anual sobre Pesquisa Básica em Doença de Chagas (Abstract 1-48). Caxambu, MG, Brasil, 1984.

28. WHO/UNDP/WB. Workshop on guidelines for multidisciplinary research on the epidemiology of Chagas' disease. Doc. TDR/EPICHA 79.1. Brasilia/Geneva, 1979 .

29. Zeledón R. El problema de la tripanosomiasis americana o enfermedad de Chagas en Costa Rica. Tesis, Ministério de Salud Pública n. 2, 1952.

30. Zeledón R. Epidemiology, modes of transmission and reservoir hosts of Chagas' disease. In Trypanosomiasis and Leishmaniasis with special reference to Chagas' disease. Ciba Foundation Symposium 20 (New Series), Elsevier Excerpta Medica, p. 51-77, 1974.

31. Zeledón R. Effects of Triatomine behavior on Trypanosome transmission. In: New Approaches in American Trypanosomiasis Research, Belo Horizonte, Brazil (1821 March, 1975). Pan American Health Organization Scientific Publication n. 318, p. 326-329, 1976. 
Zeledon R, Dias JCP, Brilla-Salazar A, Vargas LG, Urbina A. Does a spontaneous cure for Chagas' disease exist? Revista da Sociedade Brasileira de Medicina Tropical 21:15-20, Jan-Mar, 1988

32. Zeledón R, Mena C. Primer caso de enfermedad de Chagas de la Provincia de Alajuela. Revista de Biologia Tropical. 1: 55-62, 1953.

33. Zeledón R, Rabinovich JE. Chagas' disease: An ecological appraisal with special emphasis on its insect vectors. Annual Review of Entomology 26:101-33, 1981

34. Zeledón R, Solano G, Burstin L, Swartzwelder JC. Epidemiological pattem of Chagas'disease in an endemic area of Costa Rica. American Journal Tropical Medicine and Hygiene 24:214-225, 1975.

35. Zeledón R, Dias JCP, Salazar AB, Rezende JM, Vargas Guillen L. \& Urbina A. Evidências de cura espontânea de doença de Chagas em Costa Rica. II Reunião Anual de Pesquisa Aplicada em doença de Chagas, Araxá, MG. Brazil, Resumos dos Trabalhos. pág. 18, 1985. 